\title{
Correlations, partitioning and bioaccumulation of trace metals between different segments of Taylor Creek, southern Nigeria
}

\author{
E.C. Okafor and ${ }^{*}$ K. Opuene
}

Department of Pure and Industrial Chemistry, Faculty of Physical Sciences, University of Nigeria, Nsukka, Nigeria

Received 24 June 2006; revised 26 August 2006; accepted 5 September 2006; available online 1 October 2006

\begin{abstract}
Correlations between trace metals in dissolved and particulate phases, B. bayad and sediments were investigated in five selected sites along Taylor Creek, which lies between longitude $006^{\circ} 17^{I}$ to $006^{\circ} 21^{I} \mathrm{E}$ and latitude $05^{\circ} 01^{\mathrm{I}}$ to $05^{\circ} 05^{\mathrm{I}} \mathrm{N}$. The degree of correlation between the various metals was different in each of the investigated segments. Between segments, not many significant correlations were recognized. Only Ni and Cd, Mn and Cd, Mn and $\mathrm{Ni}$, and $\mathrm{Mn}$ and $\mathrm{Pb}$ are correlated in the sediments and in the particulate phase, $\mathrm{Fe}$ and $\mathrm{Cr}, \mathrm{Pb}$ and $\mathrm{Cd}$, and $\mathrm{Zn}$ and $\mathrm{Ni}$ are correlated, which suggests that the sources are not common for both compartments. Partitioning coefficients $\left(K_{d}\right)$ of trace metals between dissolved and particulate phases are generally low, which is typical for fresh water ecosystems and fairly stable over Taylor Creek all through the seasons. Furthermore, the bio-concentration factors (BCF) of $B$. bayad were low unlike those of other natural waters. Cluster analysis showed that metal accumulation in the particulate phase differed from those observed in sediments, which also confirms that the pollution of the Creek might be from different sources.
\end{abstract}

Key words: Correlations, Cluster analysis, partitioning, trace metals, B. bayad, taylor creek

\section{INTRODUCTION}

The pollution of aquatic ecosystems by trace metals is a significant problem (Rayms-Keller, et al., 1998), as trace metals constitute some of the most hazardous substances that can bio-accumulate (Tarifeno-Silva, et al., 1982). Bioaccumulation is the process in which a chemical pollutant enters the body of an organism and is not excreted but rather collected in the organism' $s$ tissues (Zweig, et al., 1999). Metals that are deposited in the aquatic environment may accumulate in the food chain and cause ecological damage while also posing a risk to human health (Grimanis, et al., 1978; Adams, et al., 1992). Taylor Creek, a non-tidal freshwater environmental unit, is situated in Gbarain clan in the Yenagoa Local Government Area of Bayelsa State in the Niger Delta. The Creek is $16 \mathrm{~km}$ and on north, northeast (NNE) from the state capital of Bayelsa State. The study environment enjoys the humid tropical climate characterized by the hot and wet conditions associated with the movement of the Interm Tropical Convergence Zone (ITCZ) north and south of the equator. As a result, the study environment has two major seasons, the dry season and the wet season and

\footnotetext{
*Corresponding author, Email: opuenekings@yahoo.com Tel.: +234 8038 916768; Fax: +234 8038916768
}

experiences consistently high temperatures (about 35 ${ }^{\circ} \mathrm{C}$ ) all year round. Since temperature varies only slightly, rainfall distribution, over space and time, becomes a single most important factor (Opuene, 2005). Monitoring programs and research for metals in environmental samples have become widely established because of concerns over accumulation and toxic effects, particularly in aquatic organisms and to humans consuming these organisms. The criteria by which organisms are accepted as biological indicator for the assessment of contamination were proposed more than twenty-five years ago and remain unchanged (Phillips, 1976). Catfishes are widely used as bioindicators of heavy metal pollution because they are known to concentrate these elements, providing a timeintegrated indication of environmental contamination. Consequently, contaminant concentrations in the tissues of catfishes more accurately reflect the magnitude of environmental contamination (Opuene, 2005). Factors known to influence metal concentrations and accumulation in catfishes include metal bioavailability, season of sampling, and hydrodynamics of the environment, size, sex, and changes in tissue composition and reproductive cycle. 
Seasonal variations have been related to a great extent to seasonal changes in flesh weight during the development of gonadic tissues (Risch, 1986).

The aim of this study was to provide inter-metal correlations in the three environmental segments: water column, sediments and B. bayad, which could present information on the source of the trace metals in Taylor Creek as well as their partitioning in the water column.

\section{MATERIALS AND METHODS}

Study area

The study area stretched from Agbia/Nedugo to Polaku along Taylor Creek, which comprised of five sampling sites. The entire stretch from Agbia/Nedugo to Polaku is about $16 \mathrm{~km}$ and lies between longitude 006 ${ }^{\circ} 17^{\prime}$ to $006{ }^{\circ} 21^{\prime} \mathrm{E}$ and latitude $05^{\circ} 01^{\prime}$ to $05^{\circ} 05^{\prime} \mathrm{N}$. Samplings of surface waters were carried out monthly for the period January 2003 to September 2004 from the sampling sites. Surface water samples were collected with nitric acid pre-rinsed 1litre plastic containers. After collection, the samples were placed in cooler boxes with ice bags whilst being transported to the laboratory and kept at about $4{ }^{\circ} \mathrm{C}$ before analysis. Samples of the catfish B. bayad were collected each month from January 2003 to September 2004 from the sampling sites. All samples of $B$. bayad were washed three times: in the freshwater, in distilled water and in freshwater again. The samples were then scrubbed in freshwater using a nylon brush, rinsed in distilled water and rinsed in freshwater to remove epifauna. Surficial sediments were collected monthly from each of the five sampling sites adjacent to where the surface waters and $B$. bayad were sampled in the period January 2003 to September 2004 by the grab method using an Eckman grab sampler on 3 to 4 locations, representing approximately $2-3 \mathrm{~cm}$ of surficial bottom sediments, within each sampling site, and wrapped with aluminum foil to avoid contamination, frozen and taken to the laboratory. Individual site (sediment) sample was thawed and air-dried at ambient temperature and pulverized to $<50 \mathrm{~mm}$ using a shatter-box grinding mill.

\section{Sample treatment and analysis}

The water samples, after filtration with the $45 \mathrm{~mm}$ Whatman filter paper, were acidified and preconcentrated. The filtrates were digested with a mixture of $10 \mathrm{~mL}$ of conc. nitric acid and $2 \mathrm{~mL}$ of conc. perchloric acid respectively. The treatment of $B$. bayad samples was based on established procedure (Opuene, 2005). Before analysis, the catfishes were dehydrated to a constant weight using an oven at $65^{\circ} \mathrm{C}$ for $20 \mathrm{~h}$ and individual whole fish pulverized to a uniform particle size. Two grams of pulverized weight were weighed using a high precision micro scale and put in a digestion flask and digested with a mixture of $10 \mathrm{~mL}$ of conc. nitric acid and $2 \mathrm{~mL}$ of conc. perchloric acid. The contents of the flask was, for each case, digested gently and slowly, by heating in a water bath until the contents got to near dryness. It was then set aside to cool. The digest was filtered into a $50 \mathrm{~mL}$ volumetric flask, and made up to mark with distilled water. Two grams of air-dried sediment samples were also weighed using a high precision microscale for each case, moistened with water and put into a $50 \mathrm{~mL}$ conical flask. To each weighed sample, 10 $\mathrm{mL}$ of conc. nitric acid and $2 \mathrm{~mL}$ of conc. perchloric acid were added and heated with a water bath to near dryness. The mild acid treatment was optimal to digest organic matter with associated metals so as to extract metals linked by adsorption to the sediments, which together represent bio available or leachable metals of the surficial sediments. Each solution was allowed to cool and subsequently filtered into a $50 \mathrm{~mL}$ volumetric flask. Following acid digestion, all samples were analysed for 7 elements: $\mathrm{Cd}, \mathrm{Cr}, \mathrm{Pb}, \mathrm{Ni}, \mathrm{Mn}, \mathrm{Zn}$ and Fe by flame atomic absorption Spectrophotometry using Buck Scientific Model 200A Spectrophotometer, equipped with a high sensitivitynebulizer. Calibration of Buck Scientific Model 200A spectrophotometer was performed before every run by successive dilution of a $100 \mathrm{mg} / \mathrm{L}$ multi-element instrument calibration standard solution that was in a range covering the concentration levels in the analysed samples. For each batch of elemental analysis, intra-run quality insurance standard (1 mg/L, multi-element standard solution) was checked for reading variation and precision of every 10 samples. Internal blanks were used to assess any background contamination originating from sample manipulation and preparation. Blanks were processed exactly as respective regular samples as well (Opuene, 2005). The accuracy of sample manipulation for the heavy metals was checked using samples of CASS-4 (seawater), PACS-2 (sediment), and DOLT-3 (organism tissue) Matrix Certified Reference Materials with known concentration for certain metals (Cantillo and Calder, 1990).

\section{Data analysis}

The relationship between inter-metal correlations in the segments of the creek was tested using Pearson Product Moment Correlation Coefficient. Relationships between the dissolved phase, particulate phase or 
suspended particulate matter (SPM) and catfish are discussed via corresponding partition coefficients and bio-concentration factors (BCF). Bio-magnification, the enrichment (positive value) or depletion (negative value) of a higher trophic level versus food was also calculated. Factor and Cluster analyses were applied on data from SPM and sediments respectively. All statistical analyses were done using Analysis Toolpak and SPSS soft- wares, with significance based on an a of 0.05 in most of the cases (Zar, 1990).

\section{RESULTS}

Tables 1-3 reports the measured values obtained for the standard reference materials for the representative metals. The percentage recoveries that validated the experimental procedures of the environmental segments were $85 \%$ for $\mathrm{Cd}, \mathrm{Fe}, \mathrm{Pb}, \mathrm{Ni}$, and $\mathrm{Zn}$ respectively. Table 4 presents the mean concentrations of trace metals studied in the dissolved phase, particulate phase, sediments and Bagrus bayad. Trace metal levels were: $\mathrm{Cd}(0.0023 \pm 0.007 \mathrm{mg} / \mathrm{mL}), \mathrm{Cr}(0.0024 \pm 0.0093), \mathrm{Fe}$ (0.49 \pm 2.63$), \mathrm{Pb}(0.0024 \pm 0.0093), \mathrm{Mn}(0.035 \pm 0.354)$, $\mathrm{Ni}(0.026 \pm 0.03)$ and $\mathrm{Zn}(0.032 \pm 0.223)$ in the dissolved phase and Cd (0.0059 $\pm 0.0076 \mathrm{mg} / \mathrm{g}$ dry weight), $\mathrm{Cr}$ (0.0062 \pm 0.0053$), \mathrm{Fe}(1.15 \pm 2.54), \mathrm{Pb}(0.019 \pm 0.02), \mathrm{Mn}$ $(0.09 \pm 0.303), \mathrm{Ni}(0.067 \pm 0.023)$ and $\mathrm{Zn}(0.083 \pm 0.181)$ in the particulate phase respectively. The mean levels of Fe in the sediments and B. bayad were $5148.0 \pm$ 49.90 and $1298.6 \pm 701.5 \mathrm{mg} / \mathrm{g}$ dry weight respectively. The second most abundant metals in the sediments and B. bayad are $\mathrm{Mn}(266.92 \pm 287.22 \mathrm{mg} / \mathrm{g}$ dry weight) and Zn (108.84 $\pm 106.02 \mathrm{mg} / \mathrm{g}$ dry weight). The metals with lower mean concentrations were: $\mathrm{Cd}(2.870 \pm 2.599$ $\mathrm{mg} / \mathrm{g}$ dry weight), $\mathrm{Cr}(3.233 \pm 4.467 \mathrm{mg} / \mathrm{g}$ dry weight), $\mathrm{Pb}(115.16 \pm 251.3)$, Ni (10.18 \pm 8.732) and $\mathrm{Zn}(107.73 \pm$ 98.61) for sediments and Cd (4.126 $\pm 2.64 \mathrm{mg} / \mathrm{g}$ dry weight), $\mathrm{Cr}$ (10.091 \pm 13.57$), \mathrm{Pb}(9.148 \pm 5.40$ ), $\mathrm{Ni}$ (11.656 $\pm 13.00)$ and $M n(42.36 \pm 27.48)$ for B. bayad. Analysis of variance $(\mathrm{P}>0.05)$ showed no significant spatial and temporal variation for the metals studied. Tables 6 to 9 present the Pearson product moment correlation coefficients of trace metals in SPM, dissolved phase, sediments and B. bayad respectively. The level of correlation between the metals was different in each of the segments. Between segments, not many significant correlations $(P<0.05)$ were recognized. Only $\mathrm{Ni}$ and $\mathrm{Cd}, \mathrm{Mn}$ and $\mathrm{Cd}, \mathrm{Mn}$ and $\mathrm{Ni}$, and $\mathrm{Mn}$ and $\mathrm{Pb}$ are correlated in the sediments and in the SPM phase, Fe and $\mathrm{Cr}, \mathrm{Pb}$ and $\mathrm{Cd}$, and $\mathrm{Zn}$ and $\mathrm{Ni}$ are correlated etc. Multivariate statistical techniques (factor analysis and cluster analysis) were used in detecting relationships between metals in SPM and sediments respectively. While factor analysis was used in reducing the number of variables from the SPM and detecting relationships between them, cluster analysis was used in grouping the variables (Figs. 1 to 4), which indicated poor correlations between the SPM and sediments respectively. Table 5 reports the absolute values of log $(K \mathrm{~d}), \log (\mathrm{BCF})$ and $\log (\mathrm{BMF})$ respectively. Partitioning coefficients $\left(K_{\mathrm{d}}\right)$ of trace metals between dissolved and SPM phases are low, which is characteristic of fresh water ecosystems and fairly stable all through the seasons.

Table 1: Measurement accuracy of standard material (CASS-4)

\begin{tabular}{clllll}
\hline Value type & $\mathrm{Cd}$ & $\mathrm{Fe}$ & $\mathrm{Pb}$ & $\mathrm{Ni}$ & $\mathrm{Zn}$ \\
\hline Certified Value & 0.026 & 0.713 & 0.0098 & 0.314 & 0.381 \\
Measured Value & $0.024(0.006)$ & $0.653(0.06)$ & $0.0088(0.002)$ & $0.304(0.01)$ & $0.361(0.02)$ \\
Recovery & $92.31 \%$ & $91.59 \%$ & $89.80 \%$ & $96.82 \%$ & $94.75 \%$ \\
\hline *The values in parentheses are standard deviations & & & &
\end{tabular}

Table 2: Measurement accuracy of standard material (PACS-2)

\begin{tabular}{llllll}
\hline \multicolumn{1}{c}{ Value type } & $\mathrm{Cd}$ & $\mathrm{Cr}$ & $\mathrm{Pb}$ & $\mathrm{Ni}$ & $\mathrm{Zn}$ \\
\hline Certified Value & 1.000 & 90.7 & 183 & 39.5 & 364 \\
Measured Value & $0.770(0.13)$ & $86.3(4.40)$ & $174(9.00)$ & $37.4(2.1)$ & $340(24)$ \\
Recovery & $87 \%$ & $94.38 \%$ & $95.08 \%$ & $94.68 \%$ & $93.41 \%$ \\
\hline *The values in parentheses are standard deviations & & & &
\end{tabular}

Table 3: Measurement accuracy of standard material (DOLT-3)

\begin{tabular}{llllll}
\hline \multicolumn{1}{c}{ Value type } & $\mathrm{Cd}$ & $\mathrm{Fe}$ & $\mathrm{Pb}$ & $\mathrm{Ni}$ & $\mathrm{Zn}$ \\
\hline Certified Value & 19.4 & 1484 & 0.319 & 2.72 & 86.60 \\
Measured Value & $17.6(1.23)$ & $1431.72(37)$ & $0.313(0.03)$ & $2.31(0.08)$ & $79.67(3.2)$ \\
Recovery & $90 \%$ & $96.48 \%$ & $98 \%$ & $85 \%$ & $92 \%$ \\
\hline *The
\end{tabular}


Table 4: Mean levels of turbidity in the surface waters and trace metals in SPM, dissolved phase, sediments and Bagrus bayad

\begin{tabular}{|c|c|c|c|c|c|c|c|}
\hline \multirow{2}{*}{ Source } & \multicolumn{7}{|c|}{ Parameter (mean \pm SD) } \\
\hline & $\mathrm{Cd}$ & $\mathrm{Cr}$ & $\mathrm{Pb}$ & $\mathrm{Ni}$ & $\mathrm{Fe}$ & $\mathrm{Mn}$ & $\mathrm{Zn}$ \\
\hline $\begin{array}{l}\text { SPM, } \mu \mathrm{g} / \mathrm{g} \text { dry } \\
\text { weight }\end{array}$ & $\begin{array}{l}0.0059 \pm \\
0.0076\end{array}$ & $0.0062 \pm 0.0053$ & $\begin{array}{l}0.019 \pm \\
0.02\end{array}$ & $0.067 \pm 0.023$ & $\begin{array}{l}1.15 \pm \\
2.54\end{array}$ & $0.09 \pm 0.303$ & $\begin{array}{l}0.083 \pm \\
0.181\end{array}$ \\
\hline $\begin{array}{l}\text { Dissolved phase, } \\
\mu \mathrm{g} / \mathrm{mL}\end{array}$ & $\begin{array}{l}0.0023 \pm \\
0.007\end{array}$ & $0.0024 \pm 0.0093$ & $\begin{array}{l}0.0079 \pm \\
0.03\end{array}$ & $0.026 \pm 0.03$ & $\begin{array}{l}0.49 \pm \\
2.63\end{array}$ & $0.035 \pm 0.354$ & $\begin{array}{l}0.032 \pm \\
0.223\end{array}$ \\
\hline $\begin{array}{l}\text { Sediments, } \mu \mathrm{g} / \mathrm{g} \\
\text { dry weight }\end{array}$ & $\begin{array}{l}2.870 \pm \\
2.599\end{array}$ & $3.233 \pm 4.467$ & $\begin{array}{l}115.16 \pm \\
251.3\end{array}$ & $10.18 \pm 8.732$ & $\begin{array}{l}5148.0 \pm \\
49.90\end{array}$ & $266.92 \pm 287.22$ & $\begin{array}{l}107.73 \pm \\
98.61\end{array}$ \\
\hline $\begin{array}{l}\text { Bagrus bayad, } \mu \mathrm{g} / \mathrm{g} \\
\text { dry weight }\end{array}$ & $\begin{array}{l}4.126 \pm \\
2.64 \\
\end{array}$ & $10.091 \pm \mathbf{P 3} .57$ & $\begin{array}{l}9.148 \pm ? \\
5.40\end{array}$ & $11.656 \pm \mathbf{P 3} .00$ & $\begin{array}{l}1298.6 \pm ? \\
701.5\end{array}$ & $42.36 \pm 27.48$ & $\begin{array}{l}108.84 \pm \\
\mathbf{1 0 6 . 0 2}\end{array}$ \\
\hline
\end{tabular}

Table 5: Absolute values of $\log (K d), \log (\mathrm{BCF})$ and $\log (\mathrm{BMF})$

\begin{tabular}{cccc}
\hline Trace metal & $\log (\mathrm{Kd})$ & $\log (\mathrm{BCF})$ & $\log (\mathrm{BMF})$ \\
\hline $\mathrm{Cd}$ & 0.41 & 3.34 & 2.93 \\
$\mathrm{Cr}$ & 0.41 & 3.67 & 3.26 \\
$\mathrm{Fe}$ & 0.41 & 3.18 & 2.76 \\
$\mathrm{~Pb}$ & 0.33 & 3.07 & 2.66 \\
$\mathrm{Mn}$ & 0.41 & 2.22 & 2.36 \\
$\mathrm{Zn}$ & 0.41 & 2.84 & 2.99 \\
$\mathrm{Ni}$ & 0.41 & 3.22 & 2.24 \\
\hline
\end{tabular}

Table 6: Pearson product moment correlation coefficients between particulate metal levels

\begin{tabular}{cccccccc}
\hline & $\mathrm{Cd}$ & $\mathrm{Cr}$ & $\mathrm{Pb}$ & $\mathrm{Ni}$ & $\mathrm{Fe}$ & $\mathrm{Mn}$ & $\mathrm{Zn}$ \\
\hline $\mathrm{Cd}$ & 1 & & & & & & \\
$\mathrm{Cr}$ & -0.61524 & 1 & & & & & \\
$\mathrm{~Pb}$ & 0.47496 & -0.1349 & 1 & & & & \\
$\mathrm{Ni}$ & 0.275733 & -0.48737 & -0.46188 & 1 & & & \\
$\mathrm{Fe}$ & -0.24305 & 0.521066 & 0.008761 & -0.60681 & 1 & & \\
$\mathrm{Mn}$ & 0.247107 & 0.105773 & 0.204431 & 0.12518 & -0.00806 & 1 & \\
$\mathrm{Zn}$ & -0.13885 & -0.27765 & -0.86775 & 0.720149 & -0.26383 & -0.11465 & 1 \\
\hline
\end{tabular}

Table 7: Pearson product moment correlation coefficients between dissolved metal levels

\begin{tabular}{cccccccc}
\hline & $\mathrm{Cd}$ & $\mathrm{Cr}$ & $\mathrm{Pb}$ & $\mathrm{Ni}$ & $\mathrm{Fe}$ & $\mathrm{Mn}$ & $\mathrm{Zn}$ \\
\hline $\mathrm{Cd}$ & 1 & & & & & & \\
$\mathrm{Cr}$ & -0.61492 & 1 & & & & & \\
$\mathrm{~Pb}$ & 0.65117 & -0.78497 & 1 & & & & \\
$\mathrm{Ni}$ & 0.274452 & -0.48817 & 0.499155 & 1 & & & \\
$\mathrm{Fe}$ & -0.24298 & 0.520656 & -0.47952 & -0.60607 & 1 & & \\
$\mathrm{Mn}$ & 0.246703 & 0.105567 & 0.281182 & 0.12561 & -0.00807 & 1 & \\
$\mathrm{Zn}$ & -0.14088 & -0.27894 & 0.249695 & 0.719814 & -0.2638 & -0.11465 & 1 \\
\hline
\end{tabular}


Correlations, partitioning and...

Table 8: Pearson product moment correlation coefficients between metal levels in sediments

\begin{tabular}{ccccccc}
\hline & $\mathrm{Cd}$ & $\mathrm{Cr}$ & $\mathrm{Pb}$ & $\mathrm{Ni}$ & $\mathrm{Fe}$ & \\
$\mathrm{Cd}$ & 1 & & & & & \\
$\mathrm{Cr}$ & 0.102928 & 1 & & & & \\
$\mathrm{~Pb}$ & -0.04827 & -0.24783 & 1 & & & \\
$\mathrm{Ni}$ & 0.949162 & 0.267419 & -0.18831 & 1 & 1 & \\
$\mathrm{Fe}$ & $-4.8 \mathrm{E}-17$ & $3.73 \mathrm{E}-16$ & $-2 \mathrm{E}-17$ & $7.23 \mathrm{E}-17$ & & \\
$\mathrm{Mn}$ & 0.63202 & 0.175812 & 0.40707 & 0.642074 & $3.88 \mathrm{E}-16$ & 1 \\
$\mathrm{Zn}$ & 0.246692 & 0.06336 & 0.120621 & 0.305322 & $1.55 \mathrm{E}-16$ & 0.393387 \\
\hline
\end{tabular}

Table 9: Pearson product moment correlation coefficients between metal levels in B. bayad

\begin{tabular}{|c|c|c|c|c|c|c|c|}
\hline & $\mathrm{Cd}$ & $\mathrm{Cr}$ & $\mathrm{Pb}$ & $\mathrm{Ni}$ & $\mathrm{Fe}$ & $\mathrm{Mn}$ & $\mathrm{Zn}$ \\
\hline $\mathrm{Cd}$ & 1 & & & & & & \\
\hline $\mathrm{Cr}$ & -0.52046 & 1 & & & & & \\
\hline $\mathrm{Pb}$ & 0.961455 & -0.41623 & 1 & & & & \\
\hline $\mathrm{Ni}$ & 0.362858 & -0.78432 & 0.310377 & 1 & & & \\
\hline $\mathrm{Fe}$ & $-3 E-16$ & $-6.8 \mathrm{E}-17$ & $1.5 \mathrm{E}-16$ & $-4.5 \mathrm{E}-17$ & 1 & & \\
\hline $\mathrm{Mn}$ & 0.47696 & -0.24023 & 0.422975 & 0.422357 & $5.55 \mathrm{E}-17$ & 1 & \\
\hline $\mathrm{Zn}$ & 0.814851 & -0.3296 & 0.781722 & 0.20287 & $2.96 \mathrm{E}-17$ & 0.525233 & 1 \\
\hline
\end{tabular}

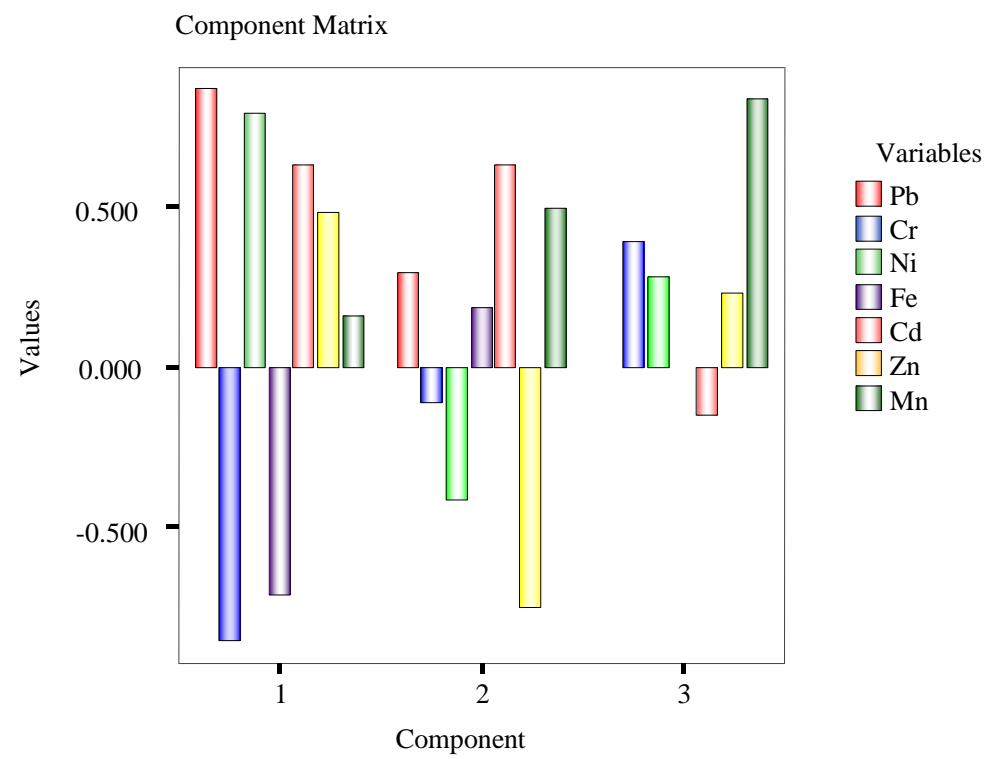

Fig. 1: Factor scores of metal concentrations in particulate matter of Taylor Creek 


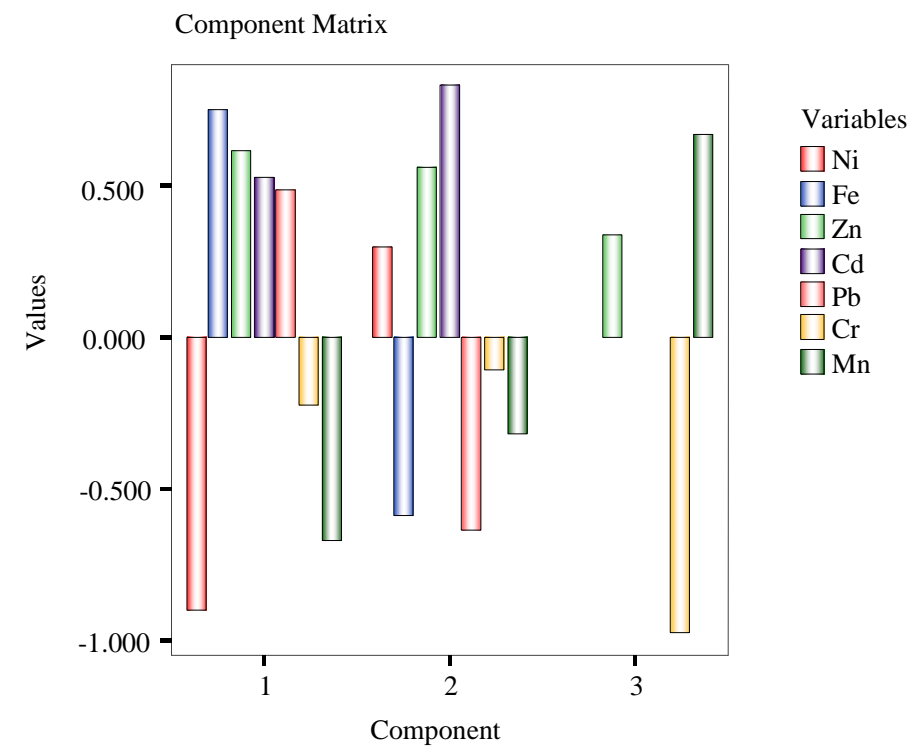

Fig. 2: Factor scores of metal concentrations in sediments of Taylor Creek

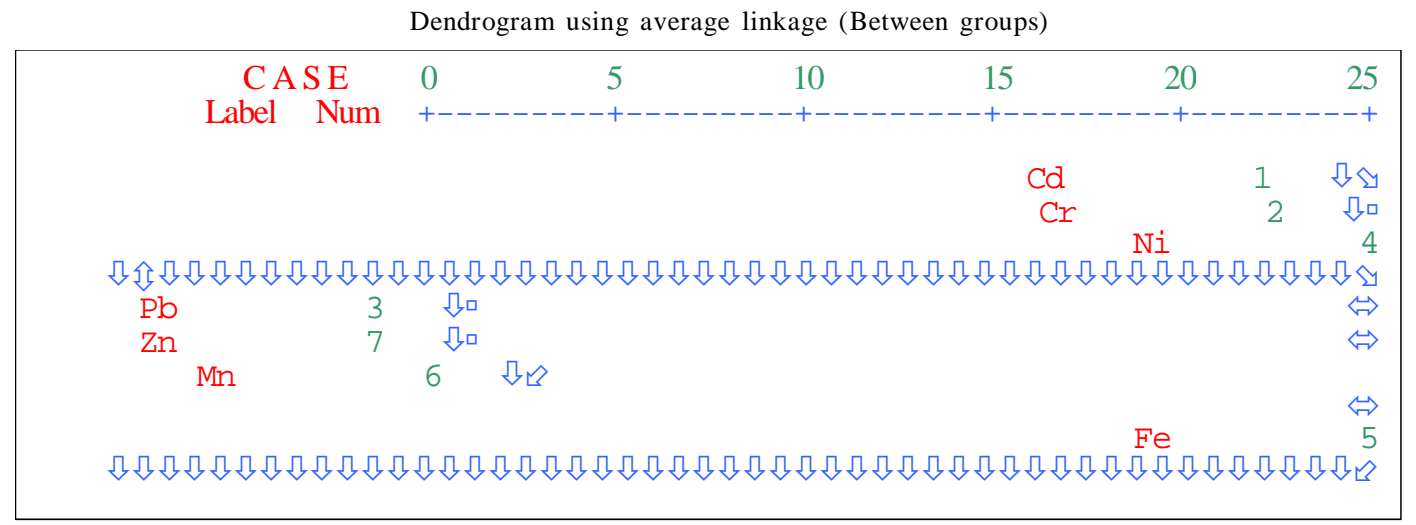

Fig. 3: Hierarchical cluster analysis dendogram of metal concentrations in sediments of Taylor Creek

Dendrogram using average linkage (Between Groups). Rescaled distance Cluster combine

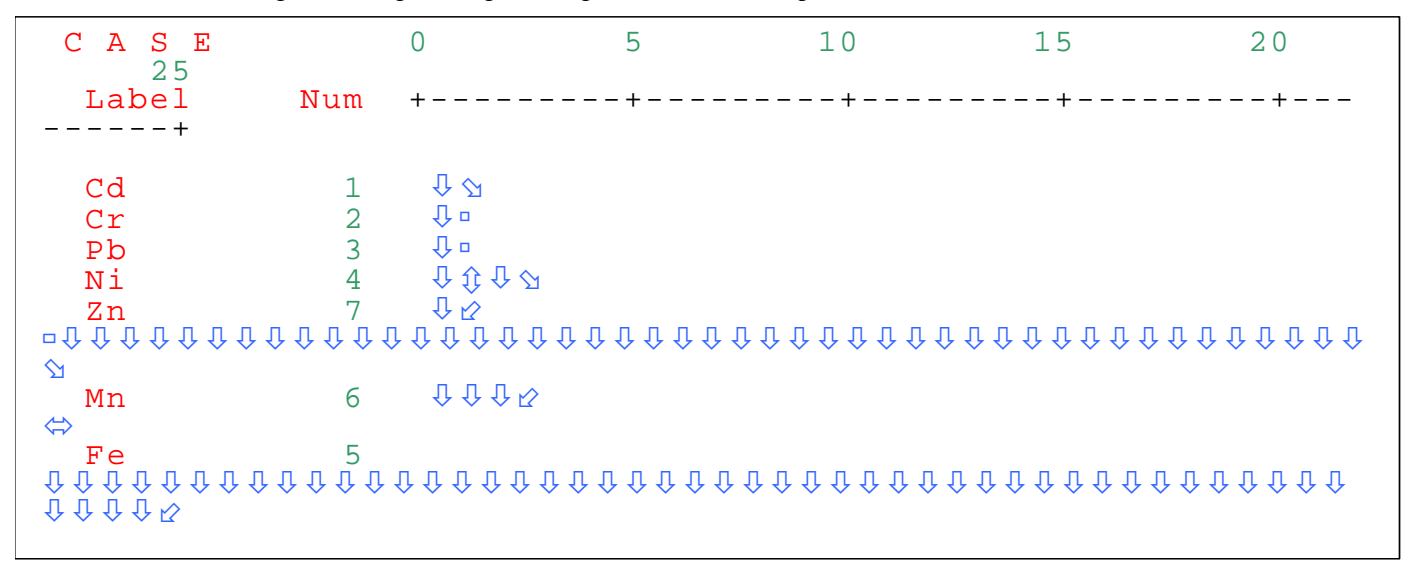

Fig. 4: Hierarchical cluster analysis dendogram of metal concentrations in particulate matter of Taylor Creek 


\section{DISCUSSION AND CONCLUSION}

The assessment of trace metals and their correlations in Taylor Creek reflected the degree of pollution, which is considered by many regulatory agencies to be one of the largest risks to the aquatic environment. The mean levels of $\mathrm{Cd}, \mathrm{Cr}, \mathrm{Pb}, \mathrm{Mn}, \mathrm{Ni}$ and $\mathrm{Zn}$ in the creek were higher than the interim standards for aquatic life and domestic use (FEPA, 1991; WHO, 1989). Based on the guidelines, direct use of water from the creek without treatment may aggravate poor health of sensitive groups (Savory and Wills, 1991). For example, the criterion for $\mathrm{Pb}$ in water for domestic use is 0 to $1.70 \mathrm{~g} /$ L (FEPA, 1991). At levels > $100 \mathrm{~g} / \mathrm{L}$, possible neurological damage in foetuses and young children may occur (Fatoki et. al., 2002). For some of the metals studied in the surface sediments, except for Cd, the levels were higher than the metal levels in the sediments of Montevideo Harbour, Uruguay (Muniz, et al., 2004). Although, it is apparent that the concentration levels of the metals may be due, partly, to catchments inwashings, oil industry activities are also implicated (Nwadinigwe and Nwaorgu, 1999). Furthermore, the study sites are located in the lower reaches of Taylor Creek suggesting that the cumulative effect of inputs from Etelebou Creek, a tributary of Taylor Creek, may be an influencing factor. In spite of the levels of trace metals in the sediments, we can deduce that the sediments presented concentrations that were at the Persaud, et. al. (1992) Severe Effect Level and may cause adverse biological effects except for $\mathrm{Cr}$, $\mathrm{Ni}$ and $\mathrm{Zn}$ respectively. For the levels of $\mathrm{Cd}, \mathrm{Cr}, \mathrm{Fe}, \mathrm{Pb}, \mathrm{Ni}, \mathrm{Mn}$ and $\mathrm{Zn}$, inter-metal correlations appear to be different in the environmental segments. While, inter-metal relationship exists between $\mathrm{Cd}-\mathrm{Ni}(\mathrm{r}=0.95)$ and considerable correlation between Cd-Mn ( $\mathrm{r}=0.63)$ and $\mathrm{Ni}-\mathrm{Mn}(\mathrm{r}=0.64)$ for the sediments; the catfish Bagrus bayad had significant correlations between $\mathrm{Cd}-\mathrm{Pb}$ ( $\mathrm{r}=0.96), \mathrm{Cd}-\mathrm{Zn}(\mathrm{r}=0.81)$, and Pb-Zn (r=0.78), which were comparable to correlation coefficients reported elsewhere (Hung, et al., 2001; Liu, et al., 2001). There was considerable correlation between $\mathrm{Mn}-\mathrm{Zn}(\mathrm{r}=0.53)$ for Bagrus bayad as well. This implies that the uptake mechanism for the metals may be the same in Bagrus bayad. In addition, concentrations of the metals in $B$. bayad have been noted to be significantly elevated when compared with the 'low background levels' in fishes of Kaduna River (Nwaedozie, 1998), which has health implications if unchecked. This is because catfishes are significant protein source in the area. In the particulate phase, there were no strong correlations between the trace metals as well. The correlation matrix shows significant inter-metal relationships $(P<0.05)$ between Ni-Zn ( $r=0.72)$. Considerable correlations between $\mathrm{Cd}-\mathrm{Pb}(\mathrm{r}=0.50)$ and $\mathrm{Cr}-\mathrm{Fe}(\mathrm{r}=0.52)$ were also observed in the particulate phase. According to Nguyen, et al. (2005), a considerable number of significant correlations in the particulate phase of Lake Balaton were observed between $\mathrm{Cr}$ and other metals. However, Jain and Sharma (2001) found very strong correlations on similar metals from the Hindon River in India. In addition, it was observed that all particulate trace metals are negatively correlated with the amount of suspended particulate matter that was similar to the trend in Hindon River (Jain and Sharma, 2001), which may be due to a dilution process of permanently suspended matter, loaded in trace metals coupled with the temporary re-suspension of bottom sediments less contaminated by metals (Nguyen, et al., 2005). Strong correlations between $\mathrm{Ni}$ and $\mathrm{Zn}$ in the SPM and dissolved phases suggest similar partitioning mechanism in Taylor Creek. The significant correlations between $\mathrm{Ni}$ and $\mathrm{Zn}$ in the two phases confirm the impact of the surrounding soil on the environmental segments. In the dissolved phase, no strong correlations between the trace metals are obvious. The best correlations, significant at $P<0.05$, are observed for $\mathrm{Ni}-\mathrm{Zn}(\mathrm{r}=0.72)$ and $\mathrm{Cd}-\mathrm{Pb}(\mathrm{r}=0.65)$. This implies that the cycling of the correlated metals may be associated. Also significant but relatively weak correlations $\left(\mathrm{r}^{3} 0.50\right)$ were observed between $\mathrm{Cr}-\mathrm{Fe}$, and $\mathrm{Pb}-\mathrm{Ni}$ respectively. Further, only few correlations between dissolved trace metals have been reported (Munksgaard and Parry, 2001). Absolute values of $K_{\mathrm{d}}$ in Taylor Creek, as presented in Table 5, is defined as the ratio of the particulate metal concentration $(\mathrm{mg} / \mathrm{kg})$ over the dissolved metal concentration (mg/L):

\section{$K_{\mathrm{d}}=\frac{\text { [particulate metal concentration }](\mathrm{mg} / \mathrm{kg})}{[\text { Dissolved metal concentration] }(\mathrm{mg} / \mathrm{L})}$}

The calculated results show that the $\log \left(K_{\mathrm{d}}\right)$ values for $\mathrm{Cd}, \mathrm{Cr}, \mathrm{Pb}, \mathrm{Fe}, \mathrm{Ni}, \mathrm{Mn}$ and $\mathrm{Zn}$ were comparatively constant and low unlike the $\log \left(K_{d}\right)$ values of the Scheldt Estuary and Lake Balaton (Baeyens, et al., 1998; Nguyen, et al., 2005). And also, $K_{d}$ values in Lake Balaton ranged from 4.3 to 6.0 in June 2000 and from 3.3 to 6.4 in September 2001 due to the influence of stormy weather conditions (Nguyen, et al., 2005), which 
shows variations between the seasons. However, the seasonal and spatial distributions of $K_{d}$ in Taylor Creek were rather stable for the metals studied. The stable $K_{\mathrm{d}}$ values of the metals may be due to the homogenisation of the dissolved metals in the Creek.

BCF and BMF are metal- and organism-dependent. BCF represents the uptake of metals into an organism from the surrounding water alone. The accumulation process involves the biological sequestering of metals that enter the organism through respiration and epidermal (skin) contact with the metals. The sequestering results in the organism having a higher concentration of the metals than the concentration in the organism's surrounding environment. Furthermore, BMF refers to bioaccumulation of metals up the food chain by transfer of the metals in smaller organisms that are food for larger organisms in the chain. It generally refers to the sequence of processes that result in higher concentrations in organisms at higher trophic levels. These processes result in an organism having higher concentrations of the metals than is present in the organism's food. BCF and BMF were calculated as follows:

$$
\begin{aligned}
& \text { BCF }=\frac{\text { [concentration of metal in B. bayad }](\mathrm{mg} / \mathrm{g})}{[\text { concentration metal in dissolved phase }](\mathrm{mg} / \mathrm{mL})} \\
& \mathrm{BMF}=\frac{[\text { concentration of metal in B. bayad }](\mathrm{mg} / \mathrm{g})}{[\text { concentration metal in SPM] }(\mathrm{mg} / \mathrm{g})}
\end{aligned}
$$

Log (BCF) values of $\mathrm{Cr}$ and $\mathrm{Zn}$ in B. bayad are the highest, whereas the lowest one is found for $\mathrm{Ni}$. The ecological distribution of the log (BCF) values was, for all trace metals, moderately stable over the Creek. Furthermore, Table 5 illustrates the absolute values of $\log (\mathrm{Kd}), \log (\mathrm{BCF})$ and $\log (\mathrm{BMF})$ of the respective environmental segments in the Creek. All logtransformed BMF values in the Creek are positive, which indicates that the metal concentration is larger in B. bayad than in SPM. Conversely, Nguyen, et al. (2005) reported that all log-transformed BMF values in Lake Balaton are negative, which means that the metal concentration is larger in suspended matter than in the organism studied. For Ni, positive but low values (log $(B M F)=2.24)$ reveal the degree of bio-magnification of this metal across the Creek. The absolute log (BMF) values of trace metals in Taylor Creek can therefore be ranked in order of decreasing magnitude: $\mathrm{Cr}(3.26)>$ $\mathrm{Zn}(2.99)>\mathrm{Cd}(2.93)>\mathrm{Fe}(2.76)>\mathrm{Pb}(2.66)>\mathrm{Mn}(2.36)$
$>\mathrm{Ni}$ (2.24). This sequence indicates that toxic metals such as $\mathrm{Cd}$, $\mathrm{Cr}$ and $\mathrm{Zn}$ are undergoing significant bioreduction from the SPM to $B$. bayad (Nguyen, et al., 2005). Furthermore, groups of similar behaving metals that were recognized in SPM using Factor analysis differed from those observed in sediments, which further confirms that pollution of this Creek might be from different sources (Figs. 1 and 2). These observations resulting from Factor analysis are also confirmed by Cluster analysis results. This is because the cluster trees of metal concentrations for the two compartments are completely different, which indicates weak correlations between sediments and SPM (Figs. 3 to 4). The relatively non-homogeneous group or case in Fig. 3 (for sediments), which could be obtained by joining lines "further up" the tree (near the right side) are dissimilar, implying that Fe and $\mathrm{Zn}$ are not similar, which further confirms the results of the Pearson product moment correlation coefficient between these metals in the sediments.

\section{REFERENCES}

Adams, W. J., Kimerle, R. A. and Barnett, J. W., (1992). Sediment quality and aquatic life assessment. Environ. Sci. Technol., 26, 1865-1875.

Adams, W. J., Kimerle, R. A. and Barnet, J. W., (1992). Sediment quality and aquatic life assessment. Environ. Sci. Technol., 26, 1865-1875.

Baeyens, W., Elskens, M., Gillain, G., and Goeyens, L., (1998). Biogeochemical behaviour of $\mathrm{Cd}, \mathrm{Cu}, \mathrm{Pb}$ and $\mathrm{Zn}$ in the Scheldt estuary during the period 1981-1983. Hydrobiol., 366, 1544.

Cantillo, A. and Calder, J., (1990). Reference materials for marine science. Fresen. J. Anal. Chem., 338, 380-382.

Fatoki O. S., Lujizan, O. and Ogunfowokan, A. O., (2002). Trace metal pollution in Umata River. Water, SA, 28 (2), 183-189.

FEPA (1991). Guidelines and Standards for environmental pollution in Nigeria.

Grimanis, A. P., Zafiropoulos, D., Vassilaki, R. and Grimanis, M., (1978). Trace elements in the flesh, and liver of two fish species from polluted and unpolluted areas in the Aegean Sea. Environ. Sci. Technol., 12, 723-726.

Hung, T. C., Meng P. J., Han, B. C., Chuang, A., and Huang, C. C., (2001). Trace metals in different species of mollusca, water and sediments from Taiwan coastal area. Chemosph., 44 (4), 833-41.

Jain, C. K., and Sharma, M. K., (2001). Distribution of trace metals in the Hindon River system, India. J. Hydro., 253 (14), $81-90$.

Liu, W. X., Li, X. D., Shen, Z. G., Wang, D. C., Wai, O. W. H., and Li, Y. S., (2003). Multivariate statistical study of heavy metal enrichment in sediments of the Pearl River Estuary. Environ. Pollut., 121 (3), 377-88. 
Muniz, P., Danulat, E., Yannicelli, B., Garcia-Alonso, J., Medina, G. and Bicego, M. C., (2004). Assessment of contamination by metals and petroleum hydrocarbons in sediments of Montevideo Harbour (Uruguay), Environ. Int., 29, 1019-1028.

Munksgaard, N. C., and Parry, D. L., (2001). Trace metals, arsenic and lead isotopes in dissolved and particulate phases of North Australian coastal and estuarine seawater. Mar. Chem., 75 (3), $165-84$.

Nguyen, H. L., Leermakers, M., Osa'n, J., To“ro“k, S., and Baeyens, W., (2005). Heavy metals in Lake Balaton: watercolumn, suspended matter, sediment and biota. Sci. Total Environ., 340 (1-3), 213-230.

Nwadinigwe, C. A. and Nwaorgu, O. N., (1999). Metal contaminants in some Nigerian Well-Head Crudes: Comparative Analysis. J. Chem. Soc. Nigeria, 24, 118-121.

Nwaedozie, J. M., (1998). The Determination of heavy metal pollution in fish samples from River Kaduna. J. Chem. Soc. Nigeria, 23, 21-23.

Persaud, D. Jaagumagi, R. and Hayton, A., (1992). Guidelines for the protection and management of aquatic sediment quality in Ontario. Ontario Ministry of the Environment, Queen's Printer for Ontario.

Opuene, K., (2005). Water quality, levels and impacts of heavy metals and polycyclic aromatic hydrocarbons (PAHs) in the Taylor Creek aquatic ecosystem, Bayelsa State. Ph.D Thesis, Department of Pure and Industrial Chemistry, University of Nigeria, Nsukka.
Philips, J., (1976). The common mussel Mytilus edulis as an indicator of zinc, cadmium, lead and copper-1. Effects of environmental variables on uptake of metals. Mar. Bio., 38, 59-69.

Risch, L. M., (1986). Check-list of the freshwater fishes of Africa (CLOFFA). ISNB, Brussels, MRAC, Tervuren; and ORSTOM, Paris, 2, 2-35.

Tarifeno-Silva, E., Kawasaki, L., Yn, D. P., Gordon, M. S. and Chapman, D. J., (1982). Aquacultural approaches to recycling dissolved nutrients in secondarily treated domestic waste waters: Uptake of dissolved heavy metals by artificial food chains. Water Res., 16, 59-65.

Zwieg, R. D., Morton, J. D., and Stewart, M. M., (1999). Source water quality for aquaculture: A guide for Assessment. the World Bank. Washington D.C.

Rayms-Keller, A., Olson, K. E., McGaw, M., Oray, C., Carlson, J. O. and Beaty, B. J., (1998). Effect of heavy metals on Aedes aegypti (Diptera Culicidea) Larvae. Ecotoxic. Environ. Safe., 39, 41-47.

Savory, J. and Wills, M. R., (1991). Aluminum. In: Merian E (ed.) metals and their compounds in the environment. occurrence, analysis and biological relevance. VCH Weinheim New York- Basel-Cambridge

WHO, (1989). Guidelines for drinking water quality, Health Criteria and Supporting Information, World Health Organization. 2, Geneva.

Zar, J. H., (1996). Biostatistical analysis. Prentice-Hall, upper Saddle River, 662.

\section{AUTHOR (S) BIOSKETCHES}

Okafor, E. Ch., Ph.D., is a lecturer in the Department of Pure and Industrial Chemistry, University of Nigeria, Nsukka, Nigeria. Email: ecokafor12@yahoo.com

Opuene, K., M.Sc., Ph.D., was a Ph.D. research student in Analytical Chemistry at the University of Nigeria, Nsukka, Nigeria.Email: opuenekings@yahoo.com

This article should be referenced as follows:

Okafor, E. Ch. and Opuene, K., (2006). Correlations, partitioning and bioaccumulation of trace metals between different segments of Taylor Creek, southern Nigeria. Int. J. Environ. Sci. Tech., 3 (4), 381-389 